\title{
The Speed and Extent of New Venture Internationalisation in the Emerging Economy Context
}

\author{
Rūta Kazlauskaitè, Erkko Autio, Tadas Šarapovas, \\ Šarūnas Abramavičius, Modestas Gelbūda
}

\begin{abstract}
A B S T R A C T
Objective: The objective of this paper is to explore to what extent the patterns of the internationalisation process described in the new venture (NV) internationalisation theory, developed on the experience and practice of advanced economy firms, apply to the emerging economy context.
\end{abstract}

Research Design \& Methods: The paper is a systematic literature review developed on the basis of peer reviewed journal articles on NV internationalisation in emerging economies. It critically evaluates the applicability of arguments proposed by the NV internationalisation theory to the emerging economy context.

Findings: In contrast to firms from advanced economies, internationalisation of NV from emerging economies is mainly driven by push factors related to their domestic markets. Transportation, communication and digital technology play a less relevant role in emerging economies; besides, their significance is more context specific; while their absence does not inhibit rapid internationalisation.

Implications \& Recommendations: To better understand the process of NV internationalisation in the emerging economy context, it is necessary to study to what extent other theoretical logics contribute to its explication. Further research should also seek to synthesise findings of research on other major theoretical frameworks.

Contribution \& Value Added: The paper contributes to the NV internationalisation theory by offering some propositions on the specifics of international entrepreneurship in the emerging economy context.

\begin{tabular}{|c|c|}
\hline $\begin{array}{l}\text { Article type: } \\
\text { Keywords: }\end{array}$ & $\begin{array}{l}\text { conceptual article } \\
\text { international entrepreneurship; entry speed; entry scope; emerging } \\
\text { economy; international new venture (INV) }\end{array}$ \\
\hline JEL codes: & M16, F23, L21, L26 \\
\hline Received: & oril $2015 \quad$ Revised: 27 April 2015 \\
\hline
\end{tabular}

\section{Suggested citation:}

Kazlauskaitè, R., Autio, E., Šarapovas, T., Abramavičius, Š., \& Gelbūda, M. (2015). The Speed and Extent of New Venture Internationalisation in the Emerging Economy Context. Entrepreneurial Business and Economics Review, 3(2), 41-52. doi: 10.15678/EBER.2015.030204 


\section{INTRODUCTION}

Emerging and transitional economies play an increasingly prominent role in the global economy. Owing to the specifics of the social, political and economic context of emerging and transitional economies, such as high environmental uncertainty, inefficient markets, and active government involvement, research from these economies has challenged existing international business theories (Xu \& Meyer, 2013). It is therefore important to critically evaluate to what extent internationalisation theories developed in advanced economy contexts are applicable to emerging and transition economies (Wright, Filatotchev, Hoskisson \& Peng, 2005; Wach, 2015). In this article we critically examine and systematically review the applicability of the international new venture theory in emerging economy contexts.

International entrepreneurship research has contributed considerably to the advancement of international business theory (Wach \& Wehrmann, 2014). In contrast to the process theory of internationalisation, which argued that firms follow an incremental path of foreign market knowledge acquisition and application in their internationalisation endeavours (Johanson \& Vahlne, 1977, 1990), the international new venture theory has proposed that new firms may seek early and proactive internationalisation to exploit opportunities in foreign markets and develop new products and services and enhance their performance (Oviatt \& McDougall, 2005). In doing that firms tend to differ in the time-span it takes them to cross the national borders. Some firms do it faster than others, i.e., from or near inception. Specifically, the international new venture theory (Oviatt \& McDougall, 1994, 2005) seeks to explain what factors explain the speed of the first foreign entry, the scope of foreign entries, and commitment to foreign sales growth.

The international new venture theory has been applied in research on emergingeconomy firm internationalisation rather extensively. Nevertheless, our understanding of international entrepreneurship across different institutional and cultural contexts remains limited (Kiss, Danis \& Cavusgil, 2012). First, prior research in the field has mainly focused on the speed and extent of internationalisation, while the country scope has been ignored by and large. It is also noteworthy that a lot of this research has been built following a case-study approach which allows identifying some forces that may have affected the speed and extent of internationalisation rather than confirming their causal effects. With reference to emerging economies, we should also remember that they are quite heterogeneous due to their institutional and cultural context specifics as well as variance in their transitional advancement from planned to market economy.

\section{MATERIAL AND METHODS}

To fill the above research gap, in our literature review we explore the following research questions, following the main arguments of the international new venture theory:

- What motives drive accelerated internationalisation and its expansion among emerging-economy firms?

- What forces enable rapid foreign market entry and foreign operation expansion among emerging-economy firms? 
- What characteristics of the entrepreneurial actor are critical in international opportunity exploitation from emerging economies?

- What resources facilitate the degree and speed of internationalisation of emergingeconomy firms?

The rest of the paper is structured as follows. First, we critically review prior research in order to identify the key motives of internationalisation among new small ventures from emerging economies. At the beginning we intended to limit our review to firms from Central and Eastern European countries; however, as research from those contexts published in quality journals turned out to be limited, we extended our review to a broader emerging economy context, without any geographical restrictions. Secondly, following the international new venture theory arguments, we overview forces that enable new ventures from these economies to enter foreign markets and consolidate their foreign operations. Next, we seek to determine the characteristics of new venture management team that are critical for new venture internationalisation success. We also offer a number of propositions that underline the distinct features of internationalising emerging economy SMEs in comparison to firms from advanced economies. We then refer to resources that were found by prior research to be critical in new venture internationalisation. Finally we offer some conclusions and implications for further research.

As regards the literature review process, we first developed a preliminary list of search terms and then supplemented it based on expert opinion. The search terms used were as follows: internationalisation, international/foreign expansion, outward FDI, export, born global, joint venture, emerging market/economy, CEE, transition market/economy/country. Next, we determined journal quality criteria and developed a list of journals to search for papers. We limited our review to journals included in Harzing (2014) list in the fields of international business, entrepreneurship, strategy and general management.

\section{LITERATURE REVIEW AND THEORY DEVELOPMENT}

\section{Motives of Rapid Internationalisation}

The international new venture theory views competition as the main motivating force of rapid internationalisation (Oviatt \& McDougall, 2005). Firms rush to enter foreign markets for fear that competitors' entry would inhibit their subsequent internationalisation efforts. Findings of research conducted in the emerging-economy context show that rapid internationalisation of small- and medium-sized enterprises (SMEs) is mainly motivated by a number of push factors related to the domestic market. Specifically case studies of Polish (Nowiński \& Rialp, 2013) and Estonian (Vissak, 2007) INVs revealed that the smallness of the domestic market was the main push factor for the SME internationalisation. Similarly, low growth potential of the domestic market was found to motivate Turkish firms to expand their foreign operations (Karadeniz \& Göçer, 2007). Instability of the domestic market was an internationalisation motive for firms from Brazil (Amal \& Rocha Freitag Filho, 2010).

The level of domestic competition is another motivating force of rapid internationalisation that has received research attention in the emerging-economy 
context. However, empirical findings on its effects on the speed and degree of internationalisation are mixed. For instance, in a study of Chinese firms Alon, Yeheskel, Lerner and Zhang (2013) found that the higher the competition at home, the more likely INVs will seek to enter a foreign market instead of looking for opportunities at home. However, another study of Chinese INVs showed that effects of domestic competition on both the speed of foreign market entry and internationalisation extent were insignificant (Naudé \& Rossouw, 2010). The effects of the level of competition in the domestic market on the degree of internationalisation were also found to be insignificant in a study of Turkish firms (Karadeniz \& Göçer, 2007). To some extent such mixed findings of the Chinese firm studies can be explained by its institutional context. Domestic government regulations were found to have a negative effect on early internationalisation, but they had a positive effect on export expansion (Naudé \& Rossouw, 2010), which is due to the fact that governmental policies are more friendly for state-owned and larger firms than INVs.

A negative country-of-origin effect in the domestic market is another push factor for firm internationalisation in transition economies. A case study of Polish INVs revealed that firms sought rapid internationalisation because domestic customers were unwilling to buy their products until they were accepted in advanced economies or were motivated to internationalisation by a lack of transparency in decision-making among domestic customers (Nowiński \& Rialp, 2013).

Given the above research findings, it can be concluded that emerging-economy firms are pushed to seek rapid internationalisation or expand their foreign operations by barriers related to their domestic market entry and its limited growth potential rather than fear of competitors' faster exploitation of the opportunity, which is the case of advanced-economy firms. We therefore raise the following proposition:

Proposition 1: Emerging-economy firms are more likely than firms from advanced economy contexts to seek early internationalisation due to domestic market entry barriers and the unattractiveness of the domestic market.

As seen from the above findings, NVI research on emerging-economy internationalisation has mainly focused on push factors. Studies on the pull factors are few in number. Among the few attempts, Nowiński and Rialp (2013) found that Polish producers of hi-end goods sought to internationalise fast due to potentially higher margins in foreign markets. Industry's degree of internationalisation was an important push and pull motivator for a Vietnamese born globals, as domestic market was either negligible or higher profits could be gained in a foreign market (Amal \& Rocha Freitag Filho, 2010; Thai \& Chong, 2008). In the first case, higher profits in a foreign market could be achieved due to lower labour costs in the domestic market, while in the latter it could be accounted by lower labour costs and by the fact that the global demand of the product (cashew nuts) exceeded its supply. These findings lead to the following proposition:

Proposition 2: Firms from emerging economies are more likely than firms from advanced economies to seek early internationalisation due to foreign market arbitrage opportunities. 


\section{Enablers of Rapid Internationalisation}

International entrepreneurship theory argues that advances in transportation and communication infrastructures and digital technology are the main forces enabling rapid internationalisation of firms (Oviatt \& McDougall, 2005). Empirical evidence from emerging economies has produced mixed results in respect to their critical role in emerging economy firm internationalisation, however. For instance, ICT technology was found to enable Polish firms to learn about target foreign markets, promote the firm, lower transaction costs and acquire customers (Nowiński \& Rialp, 2013). However, empirical evidence from Vietnam shows that limited access to ICT did not inhibit firms' learning about foreign markets or their entrance (Thai \& Chong, 2008). This suggests that the role of ICT technologies in rapid internationalisation of emerging-economy firms may be context specific. Availability of ICT technologies varies across emerging-economy countries and INVs in countries with limited access have to substitute it with other means of information acquisition (e.g. exhibitions).

Proposition 3: The quality of transportation and communication infrastructure and digital technology has a more variable impact on the speed of internationalisation among firms from different emerging economies than among firms from different advanced economies; however, its limited availability does not preclude emerging-economy firms from rapid internationalisation.

\section{Characteristics of the Entrepreneurial Actor}

The INV perspective proposes that personal characteristics (e.g. international business experience) and psychological traits (e.g. risk-taking propensity) of the entrepreneur or top management team are major moderating forces in new venture internationalisation (Oviatt \& McDougall, 2005).

Findings on the role of prior international experience in emerging-economy firm internationalisation speed and degree are mixed. For instance, prior export experience of the entrepreneur was found to be positively associated with the speed of internationalisation (Naudé \& Rossouw, 2010; Ciravegna, Majano \& Zhan, 2014). Its effects on export intensity were negative, however, which may imply that internationalisation is first and foremost sought by some INVs to enhance the firm's reputation in the domestic market (Naudé \& Rossouw, 2010). Liu et al. (2008) found in their case study that prior international experience of the entrepreneur is not necessary for rapid internationalisation. In a study of a four-country sample (China, India, Mexico and South Africa) Wood et al. (2011) found that effects of foreign education on internationalisation commitment and speed were insignificant, while foreign work experience had a positive impact. Experiential knowledge about foreign markets was accessed instead through exhibition attendance. International experience of the entrepreneur was not a necessary resource for rapid internationalisation in the case of Polish INVs either (Nowiński \& Rialp, 2013). This was successfully substituted by ICT technologies which enabled firms to learn about target foreign markets, promote the firm, lower transaction costs and acquire customers. A case study of Vietnamese bornglobals has also shown that a lack of foreign market knowledge did not serve as a barrier for early internationalisation (Thai \& Chong, 2008). Furthermore, a survey of Chinese 
early exporters revealed that INVs with top managers who had prior experience with a foreign firm were less probable to internationalise early, which again may imply that international experience is first exploited to boost a firm's competitiveness in the domestic market (Naudé \& Rossouw, 2010).

Given the above findings on the effect of international experience on the speed and degree of emerging-economy firm internationalisation, we propose the following:

Proposition 4: International business experience of the entrepreneur or top management is a less likely enabler of early internationalisation among emergingeconomy firms in comparison to their counterparts in advanced economies.

Prior research on emerging-economy firm internationalisation has looked into the effects of a number of other characteristics of the entrepreneur. For instance, global orientation of the firm management was one of the fast internationalisation enablers among Estonian born-globals (Vissak, 2007), Brasilian firms (Amal \& Rocha Freitag Filho, 2010) and among a sample of Chinese, Indian, Mexican and South African firms (Wood et al., 2011), but did not differentiate born-globals from those following the traditional process of internationalisation in a Brazilian sample (Dib, da Rocha \& da Silva, 2010). Proactiveness in the search of the first client abroad was found an important predictor of the degree and scope, but not the speed of internationalisation among Chinese SMEs (Ciravegna, Majano \& Zhan, 2014), while entrepreneurial proclivity, or opportunity driven motivation of the entrepreneur, had a positive effect on the speed of internationalisation (Alon, Yeheskel, Lerner \& Zhang, 2013). A study of Chilean firms revealed that risk-taking propensity was a predictor of the probability of a firm becoming a micro multinational corporation (MNC), while effects of innovativeness and proactiveness were insignificant (Dimitratos, Amorós, Etchebarne \& Felzensztein, 2014). Findings of a study of young INVs in China revealed that the effects of entrepreneurial proclivity on the speed of internationalisation were indirect and were mediated by foreign market knowledge (Zhou, 2007). Besides, the study showed that cultural diversity moderates the impact of innovative proclivity on foreign market knowledge.

Another study of Chinese firms found that the most important determinant of rapid internationalisation among Chinese firms was their founder's entrepreneurship (Liu, Xiao \& Huang, 2008). Furthermore the authors argue that the Chinese form of entrepreneurship is distinct from advanced-economy firms and call it "bounded entrepreneurship", for due to the institutional environment of China its entrepreneurs have lower levels of education and international experience and are faced with some unfavourable regulations. A case study of Vietnamese born-globals proposes that early internationalisation may be explained through the entrepreneur's leadership desire and the need for short-term profits (Thai \& Chong, 2008). Being generally rather autocratic in their management style, Vietnamese entrepreneurs make decisions on their business direction themselves and will seek the opportunity that they perceive as more profitable, which also emphasises the role of the national culture in identifying features of an entrepreneur that contribute to firms' rapid internationalisation in the emergingeconomy context. A longitudinal study of Polish exporters showed that rapid internationalisation was driven by positive perceptions of desirability and feasibility during the transition from the communism to the market economy, when international 
entrepreneurial initiatives were perceived more positively than purely domestic ones (Cieslik \& Kaciak, 2009).

Given the above findings on the characteristics of emerging-economy entrepreneurs that contribute to firms' rapid internationalisation, we make the following proposition:

Proposition 5: Characteristics of entrepreneurial actors of emerging-economy firms that affect new venture rapid internationalisation are more context specific than those of entrepreneurs in advanced-economy firms and may be explained through a variety of institutional and cultural context variables.

\section{Resources Facilitating Rapid Internationalisation}

Knowledge intensity in the product/service offering and international networks are the key resources that are believed by the international new venture theory to be moderating a firm's rapid internationalisation (Oviatt \& McDougall, 2005). Firms that build their competitive advantage on knowledge development and exploitation are more likely to develop skills necessary to adapt to and expand in foreign markets (Autio, Sapienza \& Almeida, 2000), while international network ties assist entrepreneurs in finding out how and where the identified opportunity can be best exploited abroad (Oviatt \& McDougall, 2005).

In the emerging economy context, knowledge intensity, as a moderating force of internationalisation, has not been given much research attention so far; furthermore, it has produced mixed results. For instance, a case study of Estonian high-tech INVs provides some support of knowledge intensity relevance, as firms under the study considered their technological competence as a unique strength that contributed to their rapid internationalisation (Vissak, 2007). A study of Turkish SMEs showed that the R\&D intensity had a positive effect on a firm's degree of internationalisation (Karadeniz \& Göçer, 2007). Higher R\&D expenses were also found to be a predictor that a firm will become a born-global rather than follow the traditional pattern of internationalization among Brazilian software firms (Dib et al., 2010). However, findings of Naudé \& Rossouw (2010) and Wood et al. (2011) studies show that the effects of R\&D spending and hightech product or technology proprietorship on the speed of internationalisation are insignificant.

Contrary to modest research efforts in respect to knowledge intensity, network influences, as another moderating force of rapid internationalisation, have received a considerably more extensive research attention in the emerging-economy context and produced some interesting findings. For instance, both international and domestic networks were found to have played a significant role in the fast internationalisation of Estonian firms (Vissak, 2007). A study of Czech SMEs, however, showed that only sharing a common language with international ties was significantly related to the speed of internationalisation, while neither the proportion of international ties nor their geographical dispersion had any significant effect on the speed of internationalisation (Musteen, Francis, \& Datta, 2010). In respect to the degree of internationalisation, the findings of the above study showed that it was positively associated with the geographical diversity of networks and negatively with the proportion of international ties, all of which undermine the relevance of international ties in respect to the speed and degree of internationalisation among emerging-economy firms. Networks were not 
a significant predictor of the speed of internationalisation among Brazilian firms either (Dib et al., 2010).

Other studies, however, showed that as international new ventures form emerging economies tend to have limited international ties, they rely more heavily on domestic networks (Nowiński \& Rialp, 2013). Besides, as mentioned above, ICT technology is often leveraged to overcome liability of foreignness. The relevance of domestic ties was also revealed in a study of Bulgarian SMEs' (Manolova, Manev \& Gyoshev, 2010), where the size of domestic personal networks of the entrepreneur were found to have a positive effect on the degree of internationalisation. The effects of inter-firm networking on the degree of internationalisation, however, were insignificant. Besides, the relationship between inter-firm networking and degree of internationalisation was negatively moderated by firm age. Findings of a survey of Chinese born-global SMEs revealed mediating effects of guanxi networks in the relationship between outward internationalisation orientation and export performance (Zhou, Wu \& Luo, 2007), which underlines the relevance of the home-based network ties in identifying global market opportunities and developing capabilities to respond to them. However, other studies of Chinese INVs showed that network effects on extent (Naudé \& Rossouw, 2010), degree and scope (Ciravegna et al., 2014) of internationalisation were insignificant or not important in facilitating internationalisation among Chinese and Vietnamese firms (Liu et al., 2008; Thai \& Chong, 2008). Furthermore, contrary to the international new venture theory, a study of young indigenous exporters in China revealed negative effects of network membership on early internationalisation, while belonging to a business group had positive effects on export in general, which implies that networks offer more advantage for domestic performance (Naudé \& Rossouw, 2010).

Proposition 6: Emerging-economy firms rely more heavily on domestic networks than advanced-economy firms in their internationalisation efforts, while international ties are not a necessary condition for emerging-economy firm rapid internationalisation.

\section{CONCLUSIONS}

The aim of this article was to critically examine the applicability of the international new venture theory in explaining the internationalisation process of new ventures from emerging and transitional economies. To attain this aim we critically studied prior research in the field.

Findings of our literature review on the motives of new venture internationalisation show that in contrast to firms from advanced economies that mainly seek rapid internationalisation due to push factors, such as fear that competitors' entry will inhibit their subsequent initiation of foreign operations, internationalisation of new ventures from emerging economies is mainly driven by push factors related to their domestic markets, such as market smallness, low growth potential, high competition, instability, negative country-of-origin effects, etc., which leads to a conclusion that rapid internationalisation of emerging economy new ventures is mainly driven by domestic market entry barriers and its unattractiveness, which distinguishes them from their advanced economy counterparts. Prior research on the pull factors, however, is very modest. Foreign market arbitrage possibilities are one of the few factors identified in our 
literature review that can be considered a specific characteristic of early emerging economy internationalisers.

Speaking of the enablers of early internationalisers, our literature review revealed that in contrast to advanced economies, where transportation, communication and digital technology were found to be among the main enablers of internationalisation, they play a less relevant role in emerging economies. Besides their significance is more context specific; while their absence does not inhibit rapid internationalisation.

Though such characteristics of entrepreneurs as international business experience, risk-taking propensity were found in the mainstream literature to be the main mediating forces of early internationalisation in advanced economy new ventures, findings on their role in emerging economies are mixed. Our findings lead to the proposition that international experience of the top management team plays a less relevant role in emerging economy firm early internationalisation and their characteristics are more context specific.

As to the resources that facilitate rapid internationalisation in the emerging economy context, our literature review revealed that the role of knowledge intensity, one of the key resources in the traditional theory, is still by and large under-researched. On the other hand, the role of network influences, another resource found to facilitate rapid internationalisation in the traditional theory, has been given extensive attention in prior research. Its findings, however, are mixed and lead to a conclusion that domestic networks are more relevant than international ties.

To conclude it may be stated that though the key arguments of the international new venture theory do apply to the emerging economy context, this theoretical logic does not fully explain the motives, enablers and moderating forces of new venture internationalisation in the emerging economy contexts and further research is needed on this phenomenon. However, our findings should be treated with reservation, as prior research on the internationalisation process of INVs is still modest and its findings are by and large derived from case studies.

Furthermore, to fully understand the process, it is necessary to study to what extent other logics, such as the process theory of internationalisation, international entrepreneurship, network theory, institutional theory, etc., contribute to its explication. Further research should also seek to synthesise findings of research built on the above major theoretical frameworks in the context of emerging economy new venture internationalisation process. It is also noteworthy that prior research on the speed and scope of internationalisation is mainly built on findings from Asian and Latin American countries, which underlines the relevance of further research in the Central and Eastern European region.

\section{REFERENCES}

Alon, I., Yeheskel, O., Lerner, M., \& Zhang, W. (2013). Internationalization of Chinese Entrepreneurial Firms. Thunderbird International Business Review, 55(5), 495-512.

Amal, M., \& Rocha Freitag Filho, A. (2010). Internationalization of small- and medium-sized enterprises: a multi case study. European Business Review, 22(6), 608-623.

Autio, E., Sapienza, H.J., \& Almeida, J.G. (2000). Effects of Age at Entry, Knowledge Intensity, and Imitability on International Growth. The Academy of Management Journal, 43(5), 909-924. 
Cieslik, J., \& Kaciak, E. (2009). The speed of internationalization of entrepreneurial start-ups in a transition environment. Journal of Developmental Entrepreneurship, 14(04), 375-392.

Ciravegna, L., Majano, S.B., \& Zhan, G. (2014). The inception of internationalization of small and medium enterprises: The role of activeness and networks. Journal of Business Research, 67(6), 1081-1089.

Dib, L., da Rocha, A., \& da Silva, J. (2010). The internationalization process of Brazilian software firms and the born global phenomenon: Examining firm, network, and entrepreneur variables. Journal of International Entrepreneurship, 8(3), 233-253.

Dimitratos, P., Amorós, J.E., Etchebarne, M.S., \& Felzensztein, C. (2014). Micro-multinational or not? International entrepreneurship, networking and learning effects. Journal of Business Research, 67(5), 908-915.

Harzing, A.W. (2014). Journal Quality List. Retrieved on March 15, 2015 from http://www.harzing.com/

Johanson, J., \& Vahlne, J.-E. (1977). The internationalization process of the firm -a model of knowledge development and increasing foreign market commitments. Journal of International Business Studies, 8(1), 23-32.

Johanson, J., \& Vahlne, J.-E. (1990). The mechanism of internationalisation. International Marketing Review, 7(4), 11-24.

Karadeniz, E.E., \& Göçer, K. (2007). Internationalization of small firms: A case study of Turkish small and medium-sized enterprises. European Business Review, 19(5), 387-403.

Kiss, A.N., Danis, W.M., \& Cavusgil, S.T. (2012). International entrepreneurship research in emerging economies: A critical review and research agenda. Journal of Business Venturing, 27(2), 266-290. doi: 10.1016/j.jbusvent.2011.09.004

Liu, X., Xiao, W., \& Huang, X. (2008). Bounded entrepreneurship and internationalisation of indigenous Chinese private-owned firms. International Business Review, 17(4), 488-508.

Manolova, T.S., Manev, I.M., \& Gyoshev, B. S. (2010). In good company: The role of personal and inter-firm networks for new-venture internationalization in a transition economy. Journal of World Business, 45(3), 257-265.

Musteen, M., Francis, J., \& Datta, D.K. (2010). The influence of international networks on internationalization speed and performance: A study of Czech SMEs. Journal of World Business, 45(3), 197-205.

Naudé, W., \& Rossouw, S. (2010). Early international entrepreneurship in China: Extent and determinants. Journal of International Entrepreneurship, 8(1), 87-111.

Nowiński, W., \& Rialp, A. (2013). Drivers and strategies of international new ventures from a Central European transition economy. Journal for East European Management Studies, 18(2), 191-231.

Oviatt, B.M., \& McDougall, P.P. (1994). Toward a theory of international new ventures. Journal of International Business Studies, 25(1)45-64.

Oviatt, B.M., \& McDougall, P.P. (2005). Defining international entrepreneurship and modeling the speed of internationalization. Entrepreneurship Theory and Practice, 29(5), 537-554.

Thai, M.T.T., \& Chong, L.C. (2008). Born-global: The case of four Vietnamese SMEs. Journal of International Entrepreneurship, 6(2), 72-100.

Vissak, T. (2007). The Emergence and Success Factors of Fast Internationalizers. Journal of EastWest Business, 13(1), 11-33.

Wach, K. (2015). Entrepreneurship without Borders: Do Borders Matter for International Entrepreneurship? Problemy Zarzqdzania, 13(1), part 2(51), 82-92. 
Wach, K., \& Wehrmann, C. (2014). Entrepreneurship in International Business: International Entrepreneurship as the Intersection of Two Fields (chapter 1). In: Gubik, A.S. \& Wach, K. (Eds.), International Entrepreneurship and Corporate Growth in Visegrad Countries (pp. 9-22). Mickolc: University of Miskolc.

Wood, E., Khavul, S., Perez-Nordtvedt, L., Prakhya, S., Velarde Dabrowski, R., \& Zheng, C. (2011). Strategic Commitment and Timing of Internationalization from Emerging Markets: Evidence from China, India, Mexico, and South Africa. Journal of Small Business Management, 49(2), 252-282. doi: j.1540-627X.2011.00324.X

Wright, M., Filatotchev, I., Hoskisson, R.E., \& Peng, M.W. (2005). Strategy Research in Emerging Economies: Challenging the Conventional Wisdom. Journal of Management Studies, 42(1), 133.

XU, D., \& Meyer, K.E. (2013). Linking theory and context:'Strategy research in emerging economies' after Wright et al.(2005). Journal of Management Studies, 50(7), 1322-1346.

Zhou, L. (2007). The effects of entrepreneurial proclivity and foreign market knowledge on early internationalization. Journal of World Business, 42(3), 281-293.

Zhou, L., Wu, W.-P., \& Luo, X. (2007). Internationalization and the performance of born-global SMEs: the mediating role of social networks. Journal of International Business Studies, 38(4), 673-690. 


\section{Authors}

Contribution share of authors is equal and amounted to $20 \%$ each of them.

\section{Rūta Kazlauskaitè}

Professor in the Area of Human Resource Management, Corporate Social Responsibility and Strategy at ISM University of Management and Economics (Lithuania). PhD in Business Administration by ISM University of Management and Economics (Lithuania).

\section{Erkko Autio}

Professor in the Area of Technology Venturing and Entrepreneurship at Innovation and Entrepreneurship Department, Imperial College London (the United Kingdom) and ISM University of Management and Economics (Lithuania). PhD by Helsinki University of Technology (Finland).

\section{Tadas Šarapovas}

Associate Professor in the Area of Economics and Strategy at ISM University of Management and Economics (Lithuania). PhD in Economics by Kaunas University of Technology (Lithuania).

\section{Šarūnas Abramavičius}

Associate Professor in the Area of Quality Management and Strategy at ISM University of Management and Economics (Lithuania). PhD in Business Administration by Kaunas University of Technology (Lithuania).

\section{Modestas Gelbūda}

Associate Professor in the Area of Strategy, Entrepreneurship and Innovation at ISM University of Management and Economics (Lithuania). PhD in Business Administration by Aalborg University (Denmark).

\section{Correspondence to:}

Assoc. Prof. Modestas Gelbūda, PhD

ISM University of Management and Economics

Arkliu Street 18

01305 Vilnius, Lithuania

modestas.gelbuda@ism.lt

\section{Acknowledgements and Financial Disclosure}

This research has been funded by the European Social Fund under the Global Grant measure (Project No. VP1-3.1-SMM-07-K-03-074).

\section{Copyright and License}

This article is published under the terms of the Creative Commons Attribution - NonCommercial - NoDerivs (CC BY-NC-ND 3.0) License http://creativecommons.org/licenses/by-nc-nd/3.0/ 